\title{
The Method of Messenger of Allah in Al Qur'an Learning
}

\author{
Ahmad Rifa'i \\ Ph.D. Student, \\ Islamic University of Jakarta, \\ Indonesia \\ Marhamah Marhamah \\ Lecturer, \\ Islamic University of Jakarta, \\ Indonesia
}

Doi: 10.36941/jesr-2020-0053

\begin{abstract}
Studying the Qur'an is the duty of every Muslim. To understand the Qur'an properly and correctly, one must imitate the method of the Prophet in teaching the Qur'an to his companions. The Prophet's method was widely distributed in his hadith which was collected in many hadith books written by scholars. Therefore there needs to be in-depth research related to this Prophet's method. The object of this research is the teaching of the Qur'an carried out by the Prophet Muhammad. The purpose of this research is to find out the method used by the Prophet Muhammad in teaching the Qur'an so that it can be replicated and applied in modern life because the teachings of the Prophet proved effective and successful. The methodology in this paper is descriptive qualitative with a historical approach and literature review. The main data sources are the Qur'an and the Hadith and the literature of the scholars. The scope of this study is the method of education of the Qur'an by the Prophet Muhammad to his companions. The research finding, the method used by Rasulullah Muhammad SAW is the best method, besides he teaches how to read the Qur'an he also teaches content and guides companions to practice it in daily life. If the method can be replicated, the problem of national morality will soon be overcome.
\end{abstract}

Keyword: The Prophet's Method, Learning the Qur'an

\section{Introduction}

Al Qur'an can be understood clearly and the messages can be captured maximally when human beings were able to read it properly. Therefore the first thing that Allah calls upon humans before conducting in-depth research and observation of the verses of Allah is the command to read. In the Surah Al Alaq Allah says:

Refer to (call) the name of your Lord Who creates (1), He has created the human being from a lump of blood (2). Read it, and your Lord is the Most Gracious (3), who teaches (human) through the mediation of kalam (4). He taught the human being what is not known (5) (QS.96: 1-5).

These verses firmly instructed human beings to read to be able to discover the majesty of Allah 
to thus Allah SWT will give generously of His. M. QuraishShihab when explaining verse three of surah Al Alaq in the above said: "The mercy of Allah almighty can deliver the man who studied the universe to discover the secrets of nature that are new and different with scientists earlier" (Shihab, 2004: 122).

In the revelation first mentioned, the command read (Iqro') is repeated two times, which showed their emphasis on the command to read it and show that reading only be successful if carried out continuously and repeatedly (Zuhailiy, 2002: 3, 2902).

Reading Al Qur'an has three levels. First, the lowest level, that can read Al Qur'an as if we read them before God. Second, testify in the heart as if God is talking to us with tenderness, giving and affection. Thirdly, being able to see who is talking in the words and see the attributes of God in the words of Al Qur'an (Pasha, 2006: 29).

In history, the Prophet has been able to instill the love of companions of the Qur'an. Prophet taught the Qur'an to the companions with various kinds of methods so that the companions at the time were encouraged to learn the Quran. For example, when the Prophet explained the war to the companions. Delivery equal to what he taught to them about the surahs of the Quran. When the verse tells about the battle of Uhud, the audience that was present at the time it took to feel what happened in the story delivered by the Prophet. So, the Qur'an at that time became part of the reality of life (Al Ghazali, 1996: 26).

Methods used by Prophet Muhammad in the teaching of the companions are not regardless of the method that is taken by the Qur'an. Because of the Prophet Muhammad is a messenger of God. He explained aspects of the law, insists on the verses and applies the Qur'an in life every day.

Al Quran is delivered step by step to him more or less twenty- three years. Rasulullah delivered Qur'an to his people and the community around it, explain the detail of the revelation of Allah and apply the laws.

The glories of the Prophet in teaching the Qur'an to his companion seen with clarity how the companions coloring of his life with the Qur'an. So that they become a generation that is called by the Prophet with the title best generation. They succeeded in applying the Qur'an in their lives, not only reading it but more than that they made the Qur'an as their view of life.

Learning to read the Quran was performed by the Prophet was reciting the Qur'an not to read the text. He recited the Qur'an to the companions according to what that he received from Jibril AS and they listened very well then repeat the recitation of the Prophet until their recitation by following the recitation of the Prophet. This method proved effective so that verse by verse was so pervasive and embedded in the hearts of companions.

Seeing the success of the Prophet Muhammad PBUH in teaching reading the Qur'an to the companions, the authors are interested in researching the Prophet's method in learning Al Quran.

Through this study, the researchers hope to get as much information about the methods that the Prophet used to teach Al Qur'an to the companions. By way of this study will be useful for anyone who wants to teach Al Qur'an.

\section{Literature Study}

The method comes from the Greek Method which means way. Ahmad Tafsir defined methods as away the most rapid and precise in doing something. The fastest and most accurate statement is the difference between method and way which also means way (Tafsir, 2008: 9).

The term learning as simple can be interpreted as an attempt to influence the emotional, intellectual, and spiritual person to be willing to learn with his will alone (Nata, 2009: 85). AECT mentioned learning as a process management environment to learn it deliberately to allow the ongoing process of learning to teach in a specific situation.

Gagne and Briggs were expressed by Sadiman suggest that learning is a series of activities (event) that affect a student or students a way such that the process of learning can take place with easy (Atmowidjoyo, 2009: 41). 
According to Syaiful Sagala, learning is to teach students to use educational principles and learning theories which are the main determinants of educational success. Learning is a two- way communication. Teaching is done by the teacher as an educator whereas studies conducted by the students.

Meanwhile, according to Corey, learning is a process in which a person-environment is on purpose managed to enable it to participate as well as the specific behavior or generate a response to a certain situation (Sagala, 2005: 61).

While Oemar Hamalik defines learning as a combination, that is composed include elements of human, material, facilities, equipment, and procedures that mutually influence to achieve the goal of learning. Humans were involved in system learning consists of students, teachers, and personnel of other, for example, energy laboratory. Materials include books, board writing, photography, slides and films, audio and videotape. Facilities and equipment consist of the room class, equipment of audio-visual and computers. Procedures include schedules and methods for delivering information, practice, study, examinations and so on (Hamalik, 2003: 61).

From the theories that put forward by the experts on learning, Oemar Hamalik proposes three formulas are considered to be more advanced than before, which is:

1. Learning is an effort to organize the environment to create the conditions of learning for students.

2. Learning is an effort to prepare the students to become good citizens who can work in the community not to be consumers, but more important is becoming a producer. To become a producer, it must have the skills to do and work within the meaning of donating himself to a good life and beneficial to the community.

3. Learning is a process of helping students deal with people's daily lives.

Thus the method of learning can be interpreted as a way the most rapid and precise in doing the activities of learning. From the above understanding, two things that need to be observed, which is the learning method is an action plan (series of activities) including the use of methods and utilization of various resources or strengths in learning, this means making of a work plan, not forming the action yet.

Methods are arranged to achieve certain goals. It means the direction of all decision-making methods is to achieve the objectives. The preparation steps of learning, the use of various facilities and sources of learning, everything is directed in an attempt to achieve the objectives. Therefore, it is necessary to determine the objectives that can be measured, because the objectives are the spirit in the implementation of a method.

Understanding the Qur'an according to the scholars in various books 'ulumul Qur'an in terms of language taken from the basic word qara'a which means to gather and unite. So, the Qur'an is essentially a collection of letters and words that become one verse, the combination of verses become a surah, a combination of surahs becomes a Qur'anic manuscript (Wahid, 2002: 24).

Definition Al Qur'an by Subhi Al Salih is as follows:

"Kalam Allah which is a miracle that descended to the Prophet Muhammad, and written in the Manuscripts and narrated by mutawatir, reading it including worship ".

With the above definition as believed by Moslems, the word of Allah revealed to the Prophet other than the Prophet Muhammad PBUH, is not called the Qur'an as the Surah which was revealed to the people of Prophet Musa AS or the Gospels which were revealed to the people of Prophet Isa. So also the word of God handed down to the Prophet Muhammad who read it are not considered as worship, such as the Hadith Qudsi, not including the Qur'an.

Reading the Qur'an is a conscious effort made by every Moslem of obtaining merit from Allah SWT accompanied by reading rules such as shortening, lengthening, thickening, refining the reading, may not stop in a forbidden place or are allowed to stop in its place, even arranging songs and rhythms until on the ethics of reading correctly (Shihab, 2005:3) 
Based on the description above, it can be concluded that the understanding of the learning method of the Qur'an according to Rasulullah PBUH is a way to teach, move and convey the Qur'an from the Prophet Muhammad to his companions through an effective and efficient learning process, both by looking at the Mushaf or not where the activity was considered worship by Allah.

\section{Research Methodology}

The method that is used in this research is descriptive qualitative method with the literature research and field visits to institutions of Qur'an learning.

In this study, researchers wanted to describe and explore data about the Qur'an recitation method carried out by Rasulullah PBUH to his companions, then analyze it so that the methods used by the Prophet can be implemented.

Data in this study were obtained from three sources:

1) Al Qur'an and Hadith Saheeh, because both are sources of Islamic law.

2) Books are written by scholars, such as the Qur'anic commentary books, Mu'tabar hadith books, dates, and books relating to the way the Prophet in teaching the Qur'an to the companions. Data sources are also obtained from informants who are experts in learning the Qur'an, both academics and practitioners so that important information is obtained that researchers can use in interpreting data.

3) Field observations of Qur'anic educational institutions.

Researchers try to get as much information about the Prophet's method in reading the Qur'an to his companions through the books of hadith, prophet's history books, Islamic religious books, magazines, journals or manuscripts that are widely available in libraries and field trips to various educational institutions Quran.

In this study, researchers perform source triangulation, by comparing data from various sources to make a valid conclusion.

\section{Research Result}

\subsection{The method of the Messenger of Allah in the Qur'an Learning}

The existence of the Prophet Muhammad, as a teacher as well as his educational material which is an apostolic task has been designed and prepared by Allah SWT as a figure in QS al-Jumu'ah: 2:

"He is the one who sent to the illiterate people an Apostle among them, who read His verses to them, purified them and taught them the Book and Wisdom (As-Sunnah). And indeed they were before really in a real digression "(QS. Al-Jumu'ah: 2)

The two verses above explained that the Prophet Muhammad sent by Allah to his people to instill knowledge while purifying their souls. Purifying means cleaning of the properties of the bad which is a habit most large communities of Mecca at the time that, as shirk, spiteful, arrogant, and worse behavior like drunkenness, depriving the rights of others and so on. Prophet Muhammad revised the way of thinking people worshiping idols until they realize of obligations to worshiping Allah as the creator, regulator, custodian beings human. Purification of the soul and awareness of the attitude of monotheism carried out by the Prophet Muhammad by considering the situation and condition of the community at that time.

Position of the Prophet Muhammad. as an educator (teacher), he expresses himself with his words:

"Indeed, Allah did not send me as a cruel and stubborn person but Allah sent me as a convert and a facilitator" (HR. Muslim.No. 2703) 
As a teacher, the Prophet Muhammad. not only oriented to the creative domain skills but also includes the dimensions of the realm of taste and intention. Even more, the Prophet Muhammad has shown perfection as an educator as well as a teacher, because in his implementation of learning has covered all aspects determined by education experts that education must be cognitive (Rasulullah PBUH. transmits knowledge and culture to others), psychomotor (Rasulullah PBUH. trains physical skills to his companions), affective (Rasulullah PBUH. always instill values and beliefs to his companions).

In the Prophet Muhammad learning method, thus generating the generation that has the intelligence of the ratio, the intelligence of the physical, the intelligence of emotion, and intelligence of spiritual, not separated from methods were applied to him in the process of learning. Here are seven methods that an overview of the various kinds of methods of education and learning that is being applied by the Prophet Muhammad in the process of learning.

\subsubsection{Exemplary Method}

In the sciences where teaching and delivery require practices such as the teaching of the Qur'an, the Prophet always did it by giving a direct example, not just theory. Even before he had done and practiced it first

Because, with hands-on practice, the effect is greater and the illustration stuck more strongly in the hearts and memories of students, because he knows firsthand the examples, evidence, and movements, so students can immediately practice it and are more motivated for it. In contrast with the only theory alone without practice.

\subsubsection{Gradual Method and Repetition}

Among the teaching methods applied by the Prophet was that he was very concerned about priorities, and taught them not all at once, but gradually, little by little and slowly, to make them easier to understand and stuck stronger in memory. One of the companions of the Prophet, Jundub bin Abdillah Ra said: "When we were still in puberty, we studied with the Prophet, and he taught us about the faith before we studied the Qur'an. After that, just we were taught (the contents and how to read) Al Qur'an. So that our faith more increased (and strengthened) (HR IbnuMajah).

In every knowledge that is delivered, he noticed the continuity between the material at the prior stage to the next stage. So that there is a connection between the material that previously with the later material. So that the students did not confuse in understanding the material that is delivered by the Prophet.

\subsubsection{Dialectical Method}

Rasulullah PBUH often took the way of discussion, dialectics, making logical comparisons, and psychological approaches. It was he used to pull out doubts and falsehood from the heart of someone who thinks that things are vanity was nice. Or to stick a suggestion about the truth in the heart of someone who was previously reluctant and tends to stay away from that truth. The method he uses is a guide for teachers and educators to use rational logic if conditions demand it.

\subsubsection{Question and Answer Method and Discussion}

The method is applied by the Prophet Muhammad to give the impression of concern to students, provide motivation, and know the potential intelligence to explain further what is already the students know. The method can be used as a standard to measure the understanding of students to material that has been given by the Prophet (explore to what extent the level of intelligence and understanding of the students). 
Prophet Muhammad always accepts the questions from the students and always gives a proportional answer (simple). Sometimes the Prophet gives a detailed answer if that is important to give more explanation that very useful for the students (An- Nahlawi, tt: 205)

\subsubsection{Props Methods and Experiment}

This is the way that he applied to show or demonstrate something that becomes an object discussion. With this method, can attract the attention of the students to what that was he taught. This method can make the students understand the material that is being taught by him easily.

In the application of this method, the Prophet sometimes using tools or objects that exist in the environment around, and sometimes also use his body.

\subsubsection{Situational and Conditional Methods}

When giving a lesson to the students, the Prophet always pay attention to the time and conditions are right for the students. It is useful so that the students do not feel weary. And make the learning proses become becomes not optimal, even become useless. because of this, the boredom needs to be anticipated.

\subsubsection{Methods of raising interest, accolade and sentence, counsel, and Motivation, as well as Reward.}

In arouse the attention of the students, the Prophet used several ways, those are repeating explanations and delay the answer, summon the students, holding hands or shoulders of the students, and switch their position. It is intended that the attention of the participant students be increased, as well as for directing the hearing, vision, and soul of the students to be physically and psychologically more prepared and more care to what that he taught.

\subsubsection{Focus on Psychological and Gradual Teaching}

Rasulullah PBUH knows the exact nature of human psychology, personality, and its specific structure. It was because he was getting the knowledge through the revelation of the creator of man and the One who oversees all affairs. God has been inserting verses in the Qur'an with a clear explanation of the essence of man, its personalities, condition of his soul, heart, and mind. Among such as that described in the Qur'an about the greatness of the soul of man and the importance of its affairs. Indeed, the soul is the awesome world and has a wide scope of discussions so feasible to think, ponder and become the object of research.

Rasulullah PBUH has applied this method in teaching. He is very concerned about the condition of the psychological person and its specific personalities. He delivered the lesson regularly and gradually so that the learning process can take place without the boredom and incriminating for people who are learning. In the case of this Abdullah bin Mas'ud said, "Rasulullah PBUH did not advise us a few days to avoid boredom" (HR. Bukhari).

\subsubsection{Focus the Difference in Student Ability}

Prophet put something in its place, and put every man in his place, and give everything by following the levels. It was narrated from his wife, Aisha RA, "Rasulullah PBUH ordered us to put a man in the places that appropriate to them (ShaheehMoslem). This is the entire rule of life. However and more applied in the learning process. Because of it, Ali bin Abi Talib once said, "Speak to the man by following what that they know. Do you want them to reject Allah and His Messenger?"(Al Bukhari). 
4.1.10 Correlating Between Knowledge With Experimentation and Evidence

Rasulullah PBUH always attempted to have the thoughts, morals, and actions taught by him firmly stuck in the hearts and minds of his students. Therefore, he correlates the thoughts and knowledge that he taught with the postulates that strengthen them, then explains them with methods that are easily understood, liked by students, accepted by reason, and by following the logic of life.

\subsubsection{Analogy (Qiyas)}

Every now and then in the teaching, the Prophet PBUH uses the analogy (comparison is figurative with forms that already exist) to law or doctrine that less can be understood well by most of his companions, also explain the causes would be a law. With the analogy, the companions were then understood against the law and the purpose of the implementation of the Shari'ah. Such that he demonstrated when a woman from the tribe Juhainah asks on him. "Indeed, My mother has vowed for Hajj, but until she died, she has not had time to hajj. Could I cover for her? "Yes, could be. Would not if your mother has a debt and has not had time to pay off, and then she died, you also have the right to pay off her debts? " Replied the Prophet." Yes, indeed so ", said the woman was relieved (Al Bukhari).

\section{Discussion}

Al Qur'an education practitioners must take the right method so that learning to read the Qur'an can be maximally successful. The method of the Prophet in teaching the Qur'an is very varied based on the situation, conditions and the mentality of the companions, this is what must be considered by practitioners. The learning method by the Prophet in teaching the Qur'an to the companions proved to be accurate. Therefore, it would be naive if Muslims do not want to adopt the Prophet's method. Here it is the way of the Prophet to teach the Qur'an that can be applied nowadays.

\subsection{Forming classical learning}

Classical according to the Dictionary of Indonesian is it together in the classroom (Depdiknas, 1991.507). Meanwhile, according to SyaifulSagala, classical learning is the activity of delivering lessons to several students, which is usually done by a teacher in the classroom.

This classical learning has been done by Rasulullah PBUH. Sometimes, he created a halaqah/group to teach the Qur'an to many people and sometimes he created small group/halaqah for particular companions.

In the phase of Makkah, he made Al Arqom's house as the central teaching of the Qur'an for his companions. Furthermore, the phase of the Medina, learning the Qur'an often in the mosque, as Aisha story, she said, "When the verse of Surah Al-Baqarah is derived which explains about usury, the Prophet PBUH out towards the mosque and recited verses in front of man, after that, Rasulullah PBUH forbid usury in buying and selling (Al Bukhari).

This classical learning is the most appropriate method to teach the Qur'an because in learning the Qur'an required musyafahah (meet face) with teachers and this method give more chance to meet the teacher so that the development of the students can be monitored well.

\subsection{Individual learning in certain circumstances}

Individual learning concern to teach the student as a person. This method can be found in classical learning also, but with a different model.

On various occasions, the Prophet, in particular, gives a lesson to the companions and sometimes The companions came to see the Prophet. As Uqbah bin Amir Ra said, "one day I follow the Prophet and he was riding his mount, then I put my hand on top of his hand and I said, "O Allah's 
Apostle, taught me a few paragraphs from the letter Hud and Joseph (IbnuHibban ).

The Qur'anneeded to be taught individually depends on the ability of the students. The student with special needs requires special treatment. It can be done only by private learning.

\subsection{Delivering the Qur'an gradually}

The Quran delivered gradually looks carefully at the student's progress. It's mean the lesson delivered little -by- little and gradually (Majid, 2008: 158).

The lesson should be given gradually increase which is from the simple to the specific, concrete to abstract, general (general) to complex, already known to the not known (an abstract concept), induction to deduction or vice versa, and often uses reinforcement (Sumiati and Asra . 2008. 33-34).

\subsection{Implement the strategy of reading the Qur'an by musyafahah}

Before reading the Qur'an, the students have to see the Quran expert directly (Musyafahah), from the root syafawi (lips to lips), meaning that both students and teachers have to see each other, look at the movement of lips while reading the Quran because the students are not going to be able to read Quran well (fashih) accordance with makhraj (point out the letters) and the character of the letters without a look at the movement of lips or mouth at the time of reading the Qur'an. Besides that, many words in the Quran with odd pronunciation that different from the general writing such as the Imam qirâ'ahsab'ah's pronunciation (qirâ'ah seven). The Prophet studied with Gabriel directly (Musyafahah) at the time of revelation, even though, substantially Allah WT that taught him. The Prophet studied with Gabriel (AS) every Ramadan to check the Prophet's reading (QS.Al Qiyamah : (75) 16-19).

The objective of Musyafahah is to keep the students' reading stay in line with what was revealed to the Prophet. If learning the Qur'an without face to face with the teacher then what happens is the pronunciation of the letters will not be suitable with the rules that should be.

\subsection{Blend the Qur'an with daily activities}

The students who just woke up from his sleep, have to read the ten last verses of Ali Imran, then Kursi and Mu'awwidzat in that day and close the day before sleep by reading last verse of al-Baqarah and oblige the students reading ten verses from any surah that they like.

\subsection{Create a new atmosphere}

Learning al Quran in the same place every day will make the students bored. therefore the teacher should be able to create a new atmosphere to make learning al Quran fun.

Rasulullah PBUH did make the mosque as a place of Qur'an reading group but he also recommends that the Qur'an was read in the house, as narrated by Anas bin Malik that the Prophet said, "Verily house which was recited the Qur'an so much kindness in it, and the house that is not recited the Qur'an have little kindness in it" (SoonanDaraquthni).

\subsection{Reciting the Qur'an}

Reciting passages of the Quran will make the students more quickly mastering the Quran reading and automatically be memorized.

Read the Qur'an is not much different from memorizing the Qur'an. If no repetition of the readings he has learned, the lessons will disappear from his memory.

In using the Prophet's method, teachers can do the following things so that the learning of the Qur'an will success. It mentioned that: 
1. Growing love for the Qur'an which can be done by telling the greatness and glory of the experts of the Qur'an, explaining the hadiths related to the glory of people who read the Qur'an.

2. Telling the stories are contained in the Qur'an, and read the verse that relates to him.

3. Persuade the students to interact with the Qur'an, as in every event that happens around them always to be connected with the Qur'an or can also be done by teaching daily prayers contained verses of the Qur'an.

4. Using the talaqqi ( face to face ) curriculum, because the Qur'an is closely related to the position of the letter exits (makhraj), therefore teachers and students must often face to face.

5. Use learning media that are relevant and not boring, for example by using VCDs containing the Qur'an, $\mathrm{MP}_{3}$ or digital Qur'an.

6. Use innovative and creative methods such as playing quizzes with Qur'anic material.

7. Requiring students to repeat reading is taught, this can be done by giving assignments to the students and the parents become companions for the students during reciting Quran at home.

8. Giving time off one day or two days a week, this is important to do so students are not bored.

9. Teach the Qur'an as well as its contents so that the number of children's memorization will be directly proportional to their understanding of the Qur'an.

\section{Conclusion}

The study of the Qur'an carried out by the Prophet Muhammad PBUH to his companions was teaching to recite verses of the Qur'an pre under what he received from Jibril AS. it is not in the meaning of prophet teach the writing of al Quran because Prophet Muhammad is illiterate which means not able to read and not be able to write.

The success of the Prophet Muhammad in teaching the Qur'an to the companions greatly supported by the smart method, creative and innovative. He understands very well that learning the Qur'an is not possible to be done in an instant, by as it is, he formed the halaqah Quran in the mosque and the companion's house. The system that he used was AlMukts that he read the Qur'an to the companion with slowly and tartil then he explains it. By way of this, the companion not only mastered reading al Quran correctly but also able to understand and capture the message. He also imposed a mu'aradhah (reciting the Quran between companions), using this even though they are not being with the Prophet, but they can be mutually honed and complementary with each other.

In general, the method that was developed by the Prophet to teach reading the Qur'an to the companions is the way talaqqi (face-to-face indirect), musyafahah (see direct the movement of the lips) and istimror (kept constant).

Methods of learning Quran which carried by the Prophet Muhammad PBUH is not only oriented on the mastery of reading the Qur'an alone but to practice of the content the Qur'an as well which then makes the companions more easily in the memorizing verses of the Qur'an.

\section{References}

Al-Bukhori, Abu Ismail, 2007. Jami' Ash-Shahih, Kairo: Dar Al-Hadits.

Departemen Agama Republik Indonesia, 2002. Al Qur'an dan Terjemahannya. Jakarta.

Al-Asqalani, Ibn al-Hajar,1978. Fath al-Bari, Kairo: Maktabah al-Kulliyat al-Azhariyyah.

Al-Asqalani, Ibn Al Hajar, 20oo. Tahdzib At Tahdzib, Beirut: Darul Kutub.

An-Nawawi, Muhyiddin, 2003. Shahih Muslim bi Syarh An-Nawawi, Kairo: Daarul Manar.

An-Nawawi, Muhyiddin, 200o. Adzkar Nawawiyyah, Surabaya: Daarul ihya al-kutuub.

An-Nawawi, Muhyiddin, 2002. ,At-Tibyan Fi Adabi Hamlat al-Qur'an, Semarang: Toha Putra. 
Ash-Shobuni, Muhammad Ali, 1985. At-Tibyan Fi Ulumil Qur'an, Surabaya: Dar Al-Ihya, Surabaya. An-Naisaburiy, Muslim Bin Hajjaj, Shahih Muslim, Thoha Putra, Semarang : Tanpa Tahun.

As-Sijistani, Sulaiman bin Al-Asy'ats, 200o. Sunan Abu Dawud, Beirut : Dar El Fikr.

Al-Majidi, Abdussalam Muqbil,20o8. Bagaimana Rasulullah Mengajarkan Al-Qur'an Kepada Para Sahabat?, Jakarta: Dar al Falah.

Abdul Fattah, Rohadi, Sudarsono, 1997. Ilmu Dan Teknologi Dalam Islam, Jakarta: Rineka Cipta, Cet.Ke-2 Abidin, Zaenal, 1992. Seluk Beluk Al Qur'an, Jakarta: Rineka Cipta.

Ad-Daromi, Abdullah Bin Abdurrahman, 1408 H. Sunan Ad-Daromi, Beirut: Darul Kitabil Arabi.

Adz-Dzahabi, Syamsuddin, 2004. Al Kasyiffi Ma'rifati Man Lahu Riwayah Fil Kutubis sittah, Lebanon: Darul Fikr.

Aj-Jurjani, Ali bin Muhammad bin Ali, 1985. At-Ta'rifat, Beirut: Darul Kitabil Arabi.

Al-Madani, Abdullah Hasyim Yamani, 1966. Sunan Ad Daruquthni, Beirut: Darul Ma'rifah.

Al-Anshoriy, Zakaria, Fathul Wahhab, ( Surabaya: Darul Ihya, tanpa tahun ).

Al-Murtadho, Zubaidi, 2005. Taajul Aruus Min Jawaahir Al Qomus, Kairo: Darul Hadits..

Al-Khatib, Muhammad Ajaj, 200o. Ushulul Hadits, Darul Fikr, Libanon.

Al-Haitsami, Ibnu Hajjar, 2007. Majma Zawaid, Kairo: Darul Hadits.

Al-Mubarrokfuriy,Abdurrohman, 2007. Tuhfatul Ahwadzi, Kairo: Darul Ihya

An-Nawawi, Muhyiddin, 2003. Syarah Arbain Nawawi, Kairo : Maktabah Aulad Syaikh Litturots.

An-Naisapuri, Al-Hakim, 20oo. Mustadrok Ala Shahihain, Riyadh:Maktabah Nizar Mustafa Al Baz.

As-Sho'ani, Muhammad Isma'il, Subulussalam, Darul Fikr, Libanon: tth

At-Tabrani, Mu'jam Kabir, Darul Khalf, Kairo : tth

At-Thobari, Ibnu Jarir, Tafsir At-Thobari, Darul Fikr, Beirut: 200

At Tirmizi, Sunan Tirmizi, Editor Hamdi Abdul Majid, Darul Khalf Jami'ah Al Azhar, Kairo : tth

Anwar, Qomari, 2002. Orientasi Pendidikan Dan Profesi Keguruan, Jakarta : UHAMKA PRESS,2002.

Arifin, H.M, 2006. Ilmu Pendidikan Islam, Jakarta : Bumi Aksara, 2006, Cet. Ke-2.

Departemen Pendidikan Nasional, 2002. Kamus Besar Bahasa Indonesia, Jakarta, Balai Pustaka, 2002, Edisi Ke-3.

Fahd bin Muhammad Al-Rummi, 1997. Ulumul Qur'an, Titian Ilahi,Yogyakarta : Titian Ilahi.

Ibnu Hambal, Ahmad 2007. Musnad Ahmad, Kairo: Darul Kutub.

Ibnu Khuzaimah, Muhammad Bin Ishaq, 1980. Shahih Ibnu Khuzaimah, Libanon: Al maktab Al Islami.

Ibnu Katsir, Abu Fida' Isma'il, Tafsir Alqur'anul Adzim, Thoha Putra, Semarang: tth

Muhaimin, Dkk, 2005. Kawasan Dan Wawasan Studi Islam, Jakarta: Kencana, Cet.Ke-1

Kartika, Esther, Memacu Minat Membaca Siswa Sekolah Dasar, Jurnal Pendidikan Penabur, No.oz/Th.III/ Desember 2004.

Khan, Ahmad, 1997. Thobaqatul Quro', Riyadh: Darul Faishal.

Nata, Abuddin 2009. Perspektif Islam Tentang Strategi Pembelajaran, Jakarta : Kencana.

Novita.E, Dewi Pembinaan Minat Baca Bagi Siswa Sekolah Dasar, Makalah Yang Disampaikan Pada Pelatihan Perpustakaan SD Singosari II Purwosari malang, o7 Juli 2007

Ramayulis, 2008. Ilmu Pendidikan Islam, Jakarta: Kalam Mulia.

Raharja, Umar Tirta, Sulo, La, Pengantar Pendidikan, ( Jakarta : Rangkap Cipta, 1995 )

Shihab, M. Quraish, 2004. Mukjizat Al Qur'an, Jakarta : Penerbit Mizan.

Shihab, M. Quraish, 20o6. Tafsir Al Mishbah, Jakarta: Lentera Hati. Cet.Ke XI

Sumiati dan Asra. 20o8. Metode Pembelajaran, Bandung: CV. Wacana Prima.

Supriyono, Kontribusi Pustakawan Dalam Meningkatkan Minat Baca, Media Pustakawan, Vol.V, nomor 3 september 1998.

Tafsir, Ahmad, 1998. Metodologi Pengajaran Agama Islam, Bandung : PT Remaja Rosda Karya.

Tarigan, Henry Guntur, 1986. Membaca Sebagai Suatu Ketrampilan Berbahasa, Bandung: Angkasa.

Yakub, Ali Mustafa, 2008. Haji Pengabdi Syetan, Jakarta: Pustaka Firdaus.

Zuhairini, Dkk, Metodik Khusus Pendidikan Agama, ( Surabaya : Usaha Nasional, 1991 ) Cet. Ke-8.

Zuhaily, Wahbah, Prof.Dr, 2004. Tafsir Al Wasith, Beirut: Maktabah Darul Kutub. 